\title{
SYNTHESIS OF 3-AMINO-2-ETHOXYCARBONYL PYRIDO[1,2-a]THIENO-[2,3-d]-4- PYRIMIDONE DERIVATIVES AND THEIR ANTIMALARIAL AND CYTOTOXIC ACTIVITIES IN VITRO.
}

\author{
Jaime Charris ${ }^{1}$, Jose Domínguez ${ }^{1}$, Mary Cordero ${ }^{1}$, Luz Orfila $^{1}$, Flavia Riggione ${ }^{1}$, Simon Lopez ${ }^{2}$, \\ Daniel Enriz ${ }^{3}$ and Fernando Suviere ${ }^{3}$. \\ 'Laboratorio de Síntesis Orgánica, Facultad de Farmacia, Universidad Central de Venezuela, \\ Aptdo. 47206, Los Chaguáramos 1041-A. Caracas Venezuela. \\ - ${ }^{2}$ Departamento de Quimica, Universidad Simon Bolívar, Caracas, Venezuela. \\ ${ }^{3}$ Departamento de Química, Universidad Nacional de San Luis, San Luis, Argentina.
}

\begin{abstract}
A series of 3-amino-2-ethoxycarbonyl pyrido[1,2-a]thieno[2,3-d]-4-pyrimidone 10-13 were prepared in order to investigate their cytotoxicity and antimalarial activities. Some of the them showed a promising activity. The detailed synthesis, spectroscopic, computational and biological data are described.
\end{abstract}

\section{Introduction}

Structures such as [1,2-a]4-pyrimidone have been studied intensively due to their biological importance (1-3). The pharmacological activities and the therapeutic effects of some pyridopyrimidones have a wide application in clinic (2). As a part of our study directed toward the synthesis of tricyclic ring systems possessing a pyrido [1,2-a] pyrimidine nucleus, we reported the synthesis of some new pyrimidone derivatives as cytotoxic and antimalarial agents.

\section{Results and discussion}

2-ethoxycarbonyl-3-hydroxypyrido[1,2-a]thieno[2,3-d]-4-pyrimidone 14 has been obtained in a multistep procedure from ethyl 2-methylthio-4-oxo-4H-pyrido[1,2-a]pyrimidine-3-carboxylate and ethyl mercapto acetate in acetonitrile, under the presence of potassium carbonate (4).<smiles>CCC(=O)c1sc2nc3ccccn3c(=O)c2c1O</smiles> 
Recently, we have reported a general procedure for the synthesis and antimalarial activity of 3amino-pyrido[1,2-a] pyrazolo[2,3-d] pyrimidin-4-ones $15-18$, by the reaction of the corresponding 2-methylthio-pyrido[1,2-a]pyrimidine-4-oxo-3-carbonitrile derivatives 6-9 with hydrazine (3).

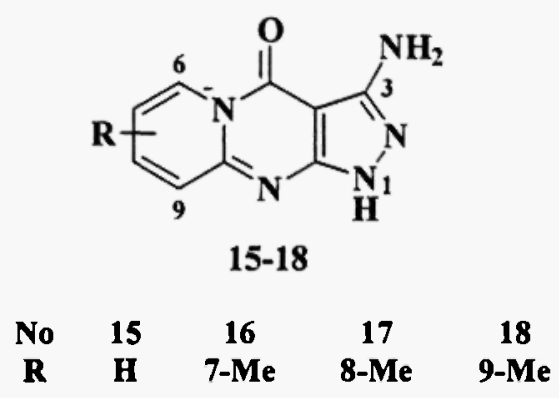

In view of the interesting biological activity exhibited by the above mentioned compounds, now we wanted to explore the effect caused by a modification on the fused hetrocyclic ring $\mathbf{c}$ by introducing a thiophene moiety. Thus, the synthesis of compounds 10-13 were accomplished by refluxing the corresponding nitriles 6-9 with an equimolecular amount of ethyl mercaptoacetate in the presence of sodium metoxide under an inert atmosphere of nitrogen. The reaction took place by a nucleophilic attack of thiolate anion on the carbon bearing the methylthio substituent, followed by a subsequent cyclization to afford compounds $\mathbf{1 0 - 1 3}$ as stable solids in good yields, as shown in the scheme 1 .

Scheme 1 .

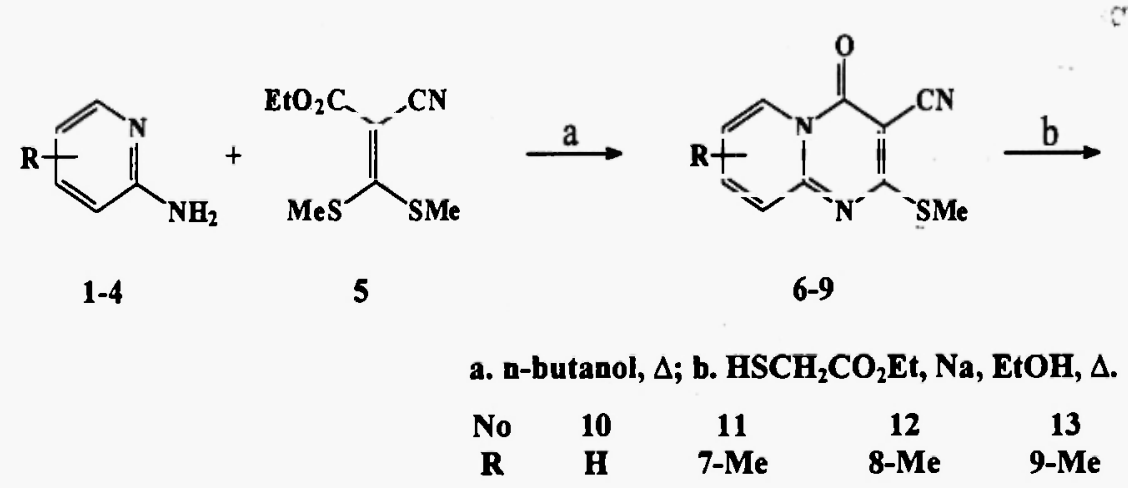

The starting nitriles 6-9 were prepared as previously described (3). The obtained compounds 10-13 were fully characterized by their analytical and spectroscopical data. Thus, they showed the presence of an $\mathrm{NH}_{2}$ group in the IR spectra (3456-3438 $\mathrm{cm}^{-1}$ ), and a carbonyl from the ester (1696$1705 \mathrm{~cm}^{-1}$ ). In the ' $\mathrm{H}$ NMR spectra, the $\mathrm{NH}_{2}$ group appears at $6.87-6.89 \mathrm{ppm}$ as a broad singlet. It is important to show that for compounds 11, 12 the methyl groups located at positions $\mathrm{C}_{7}$ and $\mathrm{C}_{8}$ respectively appeared as doblets at $2.45-2.40 \mathrm{ppm}$ with a $\mathrm{J}: 0.99 \mathrm{~Hz}$, while in compound 13 this 
coupling was not observed. Using NMR techniques, compounds 11, 12 were irradiated at the corresponding signals to $\mathrm{H}_{6}$ at $8.74 \mathrm{ppm}$ and $\mathrm{H}_{9}$ at $7.32 \mathrm{ppm}$ affording enhancements on the of $\mathrm{CH}_{3}$ signal, $(20 \%)$ and (15\%) respectively, and a disappearance of the doublet. This clearly indicated that the methyl groups at compounds 11, 12 were coupling with protons at 8.74 and $7.32 \mathrm{ppm}$ respectively. These unexpected effects were not observed by us in previously synthesized compounds 16-18. Thus, for a better understanding of the above experimental results, we conducted a conformational and electronic study on the derivatives 10-13 and their parent compounds 15-18. The purpose was to obtain more precise information about the stereoelectronic aspects that may aid in the understanding of the different accoupling obtained for these compounds in ${ }^{1} \mathrm{H}$ NMR spectra. We determined the low-energy conformations of these compounds by molecular orbital calculations. Both semiempirical AM1 and ab-initio (RHF 3-21G*) calculations, predict that the most stable forms are those in which the side-chain is located almost co-planar with respect to the rings system. Conformational potential energy surfaces (PES) of the compounds varing the torsional angles $\mathrm{Tl}$ vs T2 are shown in Figure 1 and 2.

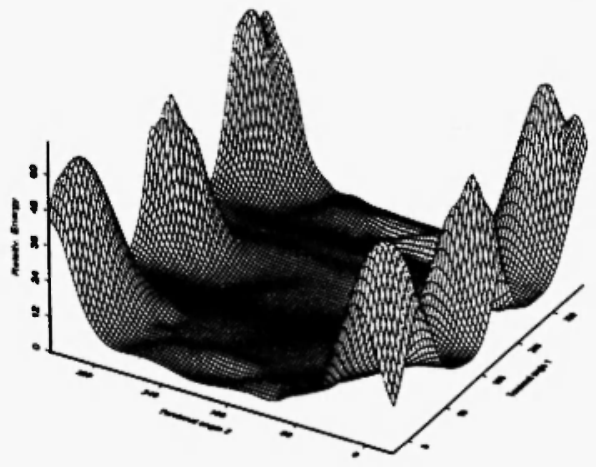

Figure 1: Conformational Potential Energy Surfaces for compounds 10-13.

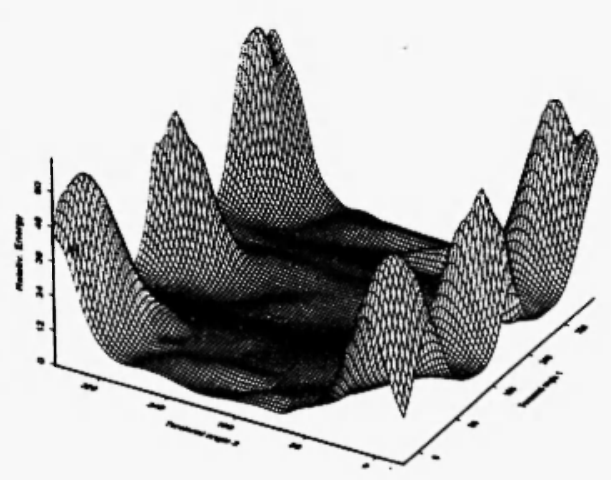

Figure 2: Conformational Potential Energy Surfaces for compounds 15-18.

Observing these PESs it is clear that the conformational behavior of these compounds is very similar. The best way to take into account all of the possible electrostatic contributions is by means of the molecular electrostatic potential maps (MEPs), evaluated at ab-initio RHF/3-21G* level. Comparing these MEPs, at least two significative differences should be noted. The first is a different electronic distribution in the vicinity of the N-H group (ring c) of compounds 15-18 in comparison with that observed near to the sulphur group of compounds 10-13. The other is the different electronic distribution on the hydrogen atoms in (ring a). This is particularly evident after 
examining the calculated partial charges in compounds 10-13 and 15-18 respectively. These results emphasize the importance of electronic effects rather than conformational factors in explaining the results observed in the ${ }^{1} \mathrm{H}$ NMR. The calculated partial charges are shown in Tablel. These molecular modeling results are in perfect agreement with the data obtained by irradiation spectrometric measurements.

Table 1: Calculated Partial Charge for derivatives 10-13 and 15-18.

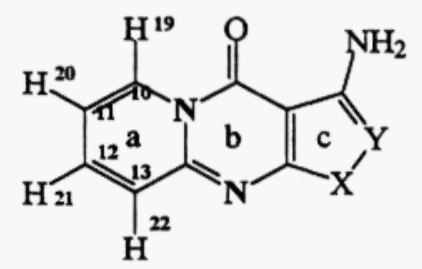

X: S or N Y: C or N

\begin{tabular}{ccc|c|c|c|c|c|c|c|}
\hline Compound & $\mathbf{C}_{\mathbf{1 0}}$ & $\mathbf{C}_{\mathbf{1 1}}$ & $\mathbf{C}_{\mathbf{1 2}}$ & $\mathbf{C}_{\mathbf{1 3}}$ & $\mathbf{H}_{\mathbf{1 9}}$ & $\mathbf{H}_{\mathbf{2 0}}$ & $\mathbf{H}_{\mathbf{2 1}}$ & $\mathbf{H}_{\mathbf{2 2}}$ \\
\hline $\mathbf{1 0}$ & 0.005 & -0.213 & -0.057 & -0.163 & 0.191 & 0.160 & 0.150 & 0.173 \\
$\mathbf{1 1}$ & -0.004 & -0.147 & -0.056 & -0.159 & 0.191 & - & 0.149 & 0.173 \\
$\mathbf{1 2}$ & 0.006 & -0.212 & 0.008 & -0.174 & 0.190 & 0.157 & - & 0.172 \\
$\mathbf{1 3}$ & -0.005 & 0.202 & -0.070 & $-0.09 \mathrm{i}$ & 0.193 & 0.160 & 0.149 & - \\
$\mathbf{1 5}$ & 0.005 & -0.218 & -0.056 & -0.166 & 0.192 & 0.158 & 0.148 & 0.171 \\
$\mathbf{1 6}$ & 0.000 & -0.155 & -0.054 & -0.165 & 0.191 & - & 0.148 & 0.171 \\
$\mathbf{1 7}$ & 0.007 & -0.216 & 0.007 & -0.175 & 0.191 & 0.157 & - & 0.171 \\
$\mathbf{1 8}$ & -0.002 & -0.211 & -0.067 & -0.097 & 0.191 & 0.158 & 0.148 & - \\
\hline
\end{tabular}

The ${ }^{13} \mathrm{C}$ NMR assignments were confirmed using a combination of DEPT $135^{\circ}$ and $90^{\circ}$, and HETCOR experiments. The mass spectra showed the presence of the respective ${ }^{-} \mathrm{m} / \mathrm{z} \mathbf{M}^{+}(100 \%$ intensity) and a peak appearing in all cases at $\mathrm{m} / \mathrm{z}: 257$, corresponding to the lost of the $\mathrm{Et}_{2} \mathrm{OH}$ group to form a stable ion.

The cytotoxicity of compounds 10-13 were studied against the growth of B16, MCF7, RD and FOG cancer cells, Vero (renal monkey cells) and primary culture from mouse and human fibroblast. The results are shown in Table 2. These data showed that compound 10 exhibited a significant cytotoxicity toward the above four cells lines. Compounds 11-13 exhibited a significant activity against the growth of $\mathrm{RD}$ cancer cells, and a moderate cytotoxicity toward B16. Compounds 11-13 were found to be inactive against Vero, MCF7 and FOG cell lines, mouse embryo fibroblast and human fibroblast. The above results indicate that the methyl group may be responsible for the selective cytotoxicity observed toward some cancer lines and that no methyl group presence increase the cytotoxic activity, which has been proposed by others (5), and further could be helpful in designing of new therapeutic agents. Preliminary antimalarial activity was evaluated against 
Plamodium falciparum in vitro, and the results are shown in Table 3 . These data show that compounds 10, 12, 13 exhibited significant activity against the inhibition of ${ }^{3}[\mathrm{H}]$-hypoxanthine incorporation at concentrations of $1 \times 10^{-3}$ and $1 \times 10^{-4} \mathrm{M}$.

Table 2. Evaluation of the Cytotoxic Potential of Compounds (10-13). Cell lines $\mathrm{LC}_{50}(\mu \mathrm{g} / \mathrm{ml})$

\begin{tabular}{cccccccc}
\hline Compound & HF & MF & Vero & MCF7 & B16 & RD & FOG \\
\hline 10 & 60 & 55 & 60 & 98 & $>>100$ & $>>100$ & $>>100$ \\
11 & $>>100$ & $>>100$ & $>>100$ & $>>100$ & $>100$ & 50 & $>100$ \\
12 & $>>100$ & $>>100$ & $>100$ & $>>100$ & $>100$ & 61 & $>>100$ \\
13 & 75 & $>>100$ & $>>100$ & $>>100$ & 76 & 57 & $>>100$ \\
\hline
\end{tabular}

HF: human fibroblast; MF: mouse fibroblast; Vero: renal monkey cells; MCF7: breast cancer; B16: melanoma; RD: rabdomiosarcome; FOG: astrocitoma.

Table 3. Evaluation of the Antimalarial Activity $\left(1 \times 10^{3}, 1 \times 10^{-4} \mathrm{M}\right)$ of compounds (10-13) against a chloroquine-resistant strain of Plasmodium falciparum.

\begin{tabular}{|c|c|c|}
\hline Compound & $\%$ inhibition $^{2}$ & $\%$ inhibition $^{b}$ \\
\hline 10 & 82 & 71 \\
\hline 11 & c & c \\
\hline 12 & 70 & 63 \\
\hline 13 & $83^{\prime}$ & 81 \\
\hline
\end{tabular}

a. $1 \times 10^{-3}$ ivi, b. $1 \times 1 \hat{w}^{-4}$ ivíc c. untested

\section{Experimental}

Melting points were determined in a Fisher melting point apparatus and are uncorrected. The IR spectra were recorded on a Shimadzu 470 spectrophotometer in $\mathrm{KBr}$ discs. The NMR spectra were recorded on a JEOL $270 \mathrm{MHz}$ spectrometer using TMS as an internal standard. The chemical shifts are expressed as $\delta$ ppm. Mass spectra were obtained using an HP 5890 spectrometer with $70 \mathrm{eV}$ ionization potential. Elemental analysis were obtained from Atlantic Microlab Inc (Norcross, GA) and are within $\pm 0.4 \%$ of the theoretical values. All chemicals and solvents were purchased from Aldrich Chemical. In the case where dry solvent were required, EtOH were destilled from $\mathrm{Mg}$ metal. Theoretical calculations were performed using the AM1 semi-empirical method contained in the MOPAC package (6) and ab-initio RHF/3-21G* computations from the gaussian 94 suite of program (7). We made a complete molecular geometry optimization in each case, without any symmetry constraint, via the energy gradient method (8-10) contained in the gaussian 94 program. The electronic study of the molecules was carried out using Molecular Electrostatic Potentials (MEP) from the SPARTAN program (11). 
Pyrido[1,2-a]pyrimido-4-one 6-9.

These compounds were obtained by following the method previously reported (3).

General procedure for synthesis of 3-amino-2-ethoxycarbonylpyrido[1,2-a]thieno[2,3-d]pyrimidot-one derivatives 10-13.

A mixture of the appropiate pyridopyrimidine $6-90.3 \mathrm{~g}(1.3 \mathrm{mmol})$, ethyl 2-mercatoacetate $0.15 \mathrm{~g}$ $(1.3 \mathrm{mmol})$, sodium $(0.04 \mathrm{at} / \mathrm{g})$ in dry ethanol $(5 \mathrm{ml})$ was refluxed for 4 hours. The solvent was evaporated to dryness under reduced pressure, water was added $(10 \mathrm{ml})$ and the solid thus obtained was colected by filtration. Further purification was accomplished by recrystalization from DMF/EtOH (1:3).

3-amino-2-ethoxycarboylpyrido[1,2-a]thieno [2,3-d]pyrimido-4-one 10.

The compound was obtained as yellow solid yield (83\%), mp 186-187 C; $\mathrm{IR}(\mathrm{KBr}): 3456\left(\mathrm{NH}_{2}\right)$, $1699(\mathrm{C}=0) \mathrm{cm}^{-1} ;{ }^{1} \mathrm{H} \mathrm{NMR}\left(\mathrm{CDCl}_{3}\right): 1,36\left(3 \mathrm{H}, \mathrm{t}, \mathrm{CH}_{2} \mathrm{CH}_{3}, \mathrm{~J}: 7.2 \mathrm{~Hz}\right), 4.30\left(2 \mathrm{H}, \mathrm{q}, \mathrm{CH}_{2} \mathrm{CH}_{3}, \mathrm{~J}: 7.2 \mathrm{~Hz}\right)$, 6.88(2H, brs, $\left.\mathrm{NH}_{2}\right), 7.05\left(1 \mathrm{H}, \mathrm{dd}, \mathrm{H}_{8}, \mathrm{~J}: 6.9 \mathrm{~Hz}\right), 7.54\left(2 \mathrm{H}, \mathrm{d}, \mathrm{H}_{9}, \mathrm{~J}: 8.9 \mathrm{~Hz}\right), 7.70\left(1 \mathrm{H}, \mathrm{dd}, \mathrm{H}_{7}, \mathrm{~J}: 6.9 \mathrm{~Hz}\right)$, 8.94(1H, d, $\left.\mathrm{H}_{6}, \mathrm{~J}: 7.2 \mathrm{~Hz}\right) ;{ }^{13} \mathrm{C}$ NMR: $14.24,60.10,91.25,107.49,114.43,125.96,127.19,136.64$, $149.94,151.39,155.27,165.16,167.07$; MS: $\mathrm{m} / \mathrm{z}$ (intensity \%) $289\left(\mathrm{M}^{+}, 100 \%\right)$.

Anal. Calcd. for $\mathrm{C}_{13} \mathrm{H}_{11} \mathrm{~N}_{3} \mathrm{O}_{3} \mathrm{~S}$ (289.32): C, 53.97; H, 3.83; N, 14.52. Found: C,53.80; H; 3.85; N, 14.54 .

3-amino-2-ethoxycarbonyl-7-methylpyrido[l,2-a]thieno[2,3-d]pyrimido-4-one 11.

The compound was obtained as yellow solid yield (79\%), mp 174-176 C; IR (KBr): $3456\left(\mathrm{NH}_{2}\right), 1693$ $(\mathrm{C}=\mathrm{O}) \mathrm{cm}^{-1} ;{ }^{1} \mathrm{H} \mathrm{NMR}\left(\mathrm{CDCI}_{3}\right): 1.36\left(3 \mathrm{H}, \mathrm{t}, \mathrm{CH}_{2} \mathrm{CH}_{3}, \mathrm{~J}: 7.2 \mathrm{~Hz}\right), 2.40\left(3 \mathrm{H}, \mathrm{d}, \mathrm{CH}_{3}, \mathrm{~J}: 0.99 \mathrm{~Hz}\right), 4.29(2 \mathrm{H}$, q, $\left.\mathrm{CH}_{2} \mathrm{CH}_{3}, \mathrm{~J}: 7.2 \mathrm{~Hz}\right), 6.89\left(2 \mathrm{H}\right.$, brs, $\left.\mathrm{NH}_{2}\right), 7.48\left(1 \mathrm{H}, \mathrm{dd}, \mathrm{H}_{9}, \mathrm{~J}_{1}: 9.2 \mathrm{~Hz}, \mathrm{~J}_{2}: 0.74 \mathrm{~Hz}\right), 7.55\left(1 \mathrm{H}, \mathrm{dd}, \mathrm{H}_{8}\right.$, $\left.\mathrm{J}_{1}: 9.2 \mathrm{~Hz}, \mathrm{~J}_{2}: 2.0 \mathrm{~Hz}\right), 8.74\left(1 \mathrm{H}, \mathrm{m}, \mathrm{H}_{6},\right),{ }^{13} \mathrm{C}$ NMR: $14.22,17.94,60.07,91.77,107.44,124.39,124.75$, 125.36, 139.77, 149.02, 151.24, 155.24, 165.23, 167.23; MS: $\mathrm{m} / \mathrm{z}$ (intensity, \%) $303\left(\mathrm{M}^{+}, 100 \%\right)$. Anal. Calcd. for $\mathrm{C}_{14} \mathrm{H}_{13} \mathrm{~N}_{3} \mathrm{O}_{3} \mathrm{~S}$ (303.34): C,55.43; H, 4.32; N, 13.55. Found: C, 55.12; H, 4,39; N, 13.67 .

3-amino-2-ethoxycarbonyl-8-methylpyrido[l,2-a]thieno[2,3-d]pyrimido-4-one 12.

The compound was obtained as yellow solid yield $(91 \%)$, mp 239-240 $\mathrm{C}$; $\mathbb{R}(\mathrm{KBr}): 3472\left(\mathrm{NH}_{2}\right), 1705$ $(\mathrm{C}=\mathrm{O}) \mathrm{cm}^{-1} ;{ }^{1} \mathrm{H} \mathrm{NMR}\left(\mathrm{CDCl}_{3}\right): 1.36\left(3 \mathrm{H}, \mathrm{t}, \mathrm{CH}_{2} \mathrm{CH}_{3}, \mathrm{~J}: 7.2 \mathrm{~Hz}\right), 2.46\left(3 \mathrm{H}, \mathrm{d}, \mathrm{CH}_{3}, \mathrm{~J}: 0.99 \mathrm{~Hz}\right), 4.29(2 \mathrm{H}$, q, $\left.\mathrm{CH}_{2} \mathrm{CH}_{3}, \mathrm{~J}: 7.2 \mathrm{~Hz}\right), 6.87\left(2 \mathrm{H}\right.$, brs, $\left.\mathrm{NH}_{2}\right), 6.88\left(1 \mathrm{H}, \mathrm{dd}, \mathrm{H} 7, \mathrm{~J}_{1}: 7.5 \mathrm{~Hz}, \mathrm{~J}_{2}: 1.7 \mathrm{~Hz}\right), 7.32\left(1 \mathrm{H}, \mathrm{m}, \mathrm{H}_{9}\right)$, 8.84(1H, d, $\left.\mathrm{H}_{6}, \mathrm{~J}: 7.5 \mathrm{~Hz}\right),{ }^{13} \mathrm{C}$ NMR: $14.22,21.24,60.04,91.70,106.72,117.27,123.86,126.45$, $149.16,150.06,151.58,155.51,166.52,167.94$; MS: $\mathrm{m} / \mathrm{z}$ (intensity, \%) $303\left(\mathrm{M}^{+}, 100 \%\right)$. 
Anal.Calcd. for $\mathrm{C}_{14} \mathrm{H}_{13} \mathrm{~N}_{3} \mathrm{O}_{3} \mathrm{~S}$ (303.34): C, 55.43; H, 4.32; N, 13.55. Found: C, 55.10; H,4.35; N, 13.54 .

\section{3-amino-2-ethoxycarbonyl-9-methylpyrido[l,2-a] thieno[2,3-d]pyrimido-4-one 13.}

The compound was obtained as yellow solid yield (87\%), mp 204-206 C; IR (KBr): $3483\left(\mathrm{NH}_{2}\right)$, $1696(\mathrm{C}=\mathrm{O}) \mathrm{cm}^{-1} ;{ }^{1} \mathrm{H} \mathrm{NMR}\left(\mathrm{CDCl}_{3}\right): 1.36\left(3 \mathrm{H}, \mathrm{t}, \mathrm{CH}_{2} \mathrm{CH}_{3}, \mathrm{~J}: 7.2 \mathrm{~Hz}\right), 2.54\left(3 \mathrm{H}, \mathrm{s}, \mathrm{CH}_{3}\right), 4.30(2 \mathrm{H}, \mathrm{q}$, $\left.\mathrm{CH}_{2} \mathrm{CH}_{3}, \mathrm{~J}: 7.2 \mathrm{~Hz}\right), 6.87\left(2 \mathrm{H}\right.$, brs, $\left.\mathrm{NH}_{2}\right), 6.96\left(1 \mathrm{H}\right.$, dd, $\left.\mathrm{H}_{7}, \mathrm{~J}_{1}: 6.9 \mathrm{~Hz}, \mathrm{~J}_{2}: 7.2 \mathrm{~Hz}\right), 7.55\left(1 \mathrm{H}, \mathrm{dd}, \mathrm{H}_{8}\right.$, $\left.\mathrm{J}_{1}: 6.7 \mathrm{~Hz}, \mathrm{~J}_{2}: 1.5 \mathrm{~Hz}\right), 8.86\left(1 \mathrm{H}, \mathrm{dd}, \mathrm{H}_{6}, \mathrm{~J}_{1}: 7.2 \mathrm{~Hz}, \mathrm{~J}_{2}: 1.5 \mathrm{~Hz}\right),{ }^{13} \mathrm{C} \mathrm{NMR}: 14.25,19.17,60.23,91.69$, $107.23,119.35,124.25,126.18,139.18,150.19$, 151.37, 155.36, 166.01, 167.78; MS: $\mathrm{m} / \mathrm{z}$ (intensity, \%) $303\left(\mathrm{M}^{+}, 100 \%\right)$.

Anal. Calcd. for $\mathrm{C}_{14} \mathrm{H}_{13} \mathrm{~N}_{3} \mathrm{O}_{3} \mathrm{~S}$ (303.34): C, 55.43; H, 4.32; N, 13.55. Found: C, 54.91; H, 4.31; N, 13.55.

\section{Cytotoxicity, antimalarial testing.}

B16, MCF7, RD, FOG cells were kindly provided by Laboratorie of Marie France Poupon, Institute Curie, Paris, France; and Vero cell line, mose embrion and human fibroblast cells were purchased from the Instituto de Biología Experimental, Facultad de Ciencias, Universidad Central de Venezuela, Caracas, Venezuela. The cytotoxic activities of tested compounds against the above seven cell lines were assayed with a modification of the MTT [3-(4,5-dimethylthiazol-2-yl)diphenyltetrazolium bromide]colorimetric method (12). The cultured cells were treated at four concentration of pure test compound ranging from 10,50,100 and $400 \mu \mathrm{g} / \mathrm{ml}$. All assays were performed in triplicate. The duration of the treatment was $24 \mathrm{~h}$. The $\mathrm{LC}_{50}$ value was defined as the concentration of test compound resulting in a $50 \%$ reduction of absorbance compared to untreated cells in the MTT assay.

The FCB1, a chloroquine-resistant strain, was originally obtained from a Colombian Patient, and maintained in continuos culture according to the techniques of Trager and Jensen (13). The culture was synchronized until ring trophozoytes using the method described by Lambros and Vanderberg (14). Drugs effects on $P$. falciparum proliferation were measured as inhibition of ${ }^{3} \mathrm{H}$-hypoxanthine incorporation into nucleic acid, using the method described by Desjardin (15).

\section{Acknowledgments}

This research was supported by grants from IIF-UCV, CDCH-UCV (PG. 06-30-4590-2000, PI. 06-304544-1999), CONICIT (Grant No. LAB. 97000665, S1 95000496). The authors thank Dr. F. Arvelo, Facultad de Ciencias, Universidad Central de Venezuela for helping with the cell lines. 


\section{References}

[1] P. L. Ferrarini, C. Mori, G. Armani, L. Rossi, Il Farmaco, 50, 69 (1995); G. Naray, I. Hermecz, Z. Meszáros, J. Chem. Soc. Perkin I, 1753 (1974); I Hermecz, Z. Mészáros, Advances in Heterocyclic Chemistry, 33, 323 (1983); I. Hermecz, Advances in Hetrocyclic Chemistry, 63, 103 (1995) and references therein; L. Selic, S. G. Groadolnik, B. Stanovnik, Heterocycles, 45, 2349 (1997); S. Strah, A. Golobic, L. Golic, B. Stanovnik, J. Heterocylic Chem., 34, 1511 (1997).

[2] I. Hermecz, Z. Mészáros, Med. Res. Rev., 8, 203 (1988).

[3] J. Dominguez, J. Charris, L. Iarrusso, S. Lopez, G. Lobo, Il Farmaco, 51, 781 (1996).

[4] M. Marchacín, J. Sultlik, A. Martvon, Collection Czechoslovak Chem. Commun., 46, 2428 (1982).

[5] R.J.Griffm, S. Srinivasan, K. Bowman, A.H. Calvert, N.J. Curtin, D.R. Newell, L.C. Pemberton, B.T. Golding, J. Med. Chem. 41, 5247 (1998).

[6] J.J.P. Stewart, MOPAC: A semiempirical Molecular Orbital Program QCPE, 455, (1983).

[7] M.J. Frisch, G.W. Trucks, H.B. Schlegel, P.M.W. Gill, B.G. Johnson, M.A. Robb, J.R. Cheeseman, T.A. Keith, G.A. Pettersson, J.A. Montgomery, K. Raghavachari, M.A. Al-Laham, V.G. Zahrzeuski, J.V. Ortiz, J.B. Forssman, J.Cioslowski, C.J. Peng, P.J. Ayala, W. Chen, M.Wong, J.L. Andres, E.S. Replogle, R. Gomperts, R.L. Martin, D.J. Fox, J.S. Binkley, D.F. Defrees, J. Baker, J.J. Stewart, M. Mead-Goordon, C. Gonzälez, J.A. Pople, Gaussian 94, Revission, Gaussian Inc. Pittsburg, P.A. (1995).

[8] C.G. Broyden. J. Inst. Math. Appl. 6, 222 (1970).

[9] R. Fletcher, Comput. J. 13, 317 (1970).

[10] D. Goldfarb, Math. Comput. 24, 647 (1970).

[11] SPARTAN version 4.0. Wave function, Inc: Irvine, CA. USA (1995).

[12] T. Mosmann, J. Immunol. Methods, 65, 55 (1983).

[13] W. Trager, J. B. Jensen, Science, 193, 673 (1976).

[14] C. Lambros, J. Vanderberg, J. Parasitol., 65, 418 (1979).

[15] R. E. Desjardin, C. J. Confield, J. D. Hagnes, J. D. Chulay, Antimicrob. Agents and Chemother. 16,710 (1979).

Received on September 20, 2000 